\title{
Tilt Angle Optimization of Photovoltaic Panels
}

\author{
Z.Rasouli Dogaheh,V. Puig,
}

\begin{abstract}
The performance of a solar radiation conversion system is affected by tilt angle with the horizontal plane. Thus, photovoltaic array needs to be tilted at the correct angle to maximize the performance of the system. In this paper, we found the optimum tilt angle and applied for Barcelona, Spain, located at latitude 410 22' 56" North and longitude 20 6'56" East. The optimal tilt angle for Winter (December, January, February) is 56.46 and the optimum tilt angle for Spring (March, April, May) is $29.11^{\circ}$ and the optimum tilt angle for Summer(Jun, July, August) is $13.76^{\circ}$ and the optimum tilt angle for Autumn (September, October, November) is $48.14^{\circ}$. Finally, the annual optimum tilt angle for our latitude is $36.87^{\circ}$, with this optimal slope angel, maximum monthly and annual solar radiation is calculated. In this way, we can increase the energy generation when achieved to maximum solar radiation. With this process, we were able to increase $10.54 \%$ of energy.
\end{abstract}

\section{INTRODUCTION}

The solar PV power sector in Spain has been developing at a spectacular rate in recent years. The need to reduce Spain's high dependence on fossil fuels, the cost of which had risen alarmingly due to constant price hikes during the years prior to the current economic crisis, made renewable energies, including photovoltaic energy, an increasingly attractive alternative. At the same time, various requirements to reduce $\mathrm{CO}_{2}$ emissions were established by the European Union and in international agreements on climate change.

The case of the city of Barcelona is a good area for using PV energy because two reasons: the first is the very long days as presented in Table 1 [1], and the second is peak sun hours (PSH) as shown in Table 2 [2]. Barcelona has a good $\mathrm{PSH}$ that facilitate the use of photovoltaic system for energy generation.

Photovoltaic energy, which produces clean electricity from the Sun, has grown faster among renewable energies, and its implementation all over the world is a guarantee of a

\footnotetext{
* This work has been partially funded by the Spanish State Research Agency (AEI) and the European Regional Development Fund (ERFD) through the projects DEOCS (ref. MINECO DPI2016-76493) and SCAV (ref. MINECO DPI2017-88403-R).This work has also been partially funded by AGAUR of Generalitat de Catalunya through the Advanced Control Systems (SAC) group grant (2017 SGR 482).

Z. Rasouli Dogaheh is with the Institute of Robotics of Universitat Politecnica de Catalunya,Campus Diagonal Sud ,Carrer de Pau Gargallo,14, CO 08028 Barcelona Spain(phone: +34 9340158 80; fax: +34 9340158 81; e-mail: zrasouli@iri.upc.edu).

V. Puig. is with the Institute of Robotics of Universitat Politecnica de Catalunya,Campus Diagonal Sud ,Carrer de Pau Gargallo,14, CO 08028 Barcelona Spain (e-mail: vicenc.puig@upc.edu).
}

TABLE 1. BARCELONA DAY LENGTH AVERAGE

\begin{tabular}{|c|c|}
\hline Month & Average of day length (hour) \\
\hline January & $9: 34: 29$ \\
\hline February & $10: 38: 17$ \\
\hline March & $11: 57: 47$ \\
\hline April & $13: 20: 50$ \\
\hline May & $14: 31: 20$ \\
\hline Jun & $14: 30: 59$ \\
\hline July & $14: 48: 49$ \\
\hline August & $13: 46: 48$ \\
\hline September & $12: 27: 17$ \\
\hline November & $9: 25: 15$ \\
\hline December & $9: 14: 39$ \\
\hline
\end{tabular}

solid and efficient energy technology. Nevertheless, in order to design very efficient solar energy systems, it is crucial to have a good solar radiation database. There are databases that consider only horizontal surfaces. Afterwards, it is necessary to transform the horizontal solar radiation data to tilt solar radiation data.

The performance of a solar PV array is highly influenced by its angle of tilt with the horizontal. This is due to the facts that tilt angle change the solar radiation reaching the surface of the PV array. The tilt angle is defined as the angle of PV arrays with respect to horizontal. It is a dominant parameter affecting the collectible radiation of a fixed PV array (see Fig. 1) [3]. In general, the optimal tilt angle of a fixed PV array is related to the local climatic condition, geographic latitude and the period of its use. Hence, different places will have different optimal tilt angles for a yearly-used solar PV array. So far, a number of studies on the optimal tilt angle of PV arrays have been conducted. Duffie and Beckman[4] proposed that $B_{\mathrm{opt}}=(\varnothing+/-15)+/-15$ and Heywood [5], suggested $B_{\text {opt }}=(\varnothing+/-15)$ where in these formulas $\varnothing$ latitude of the location.

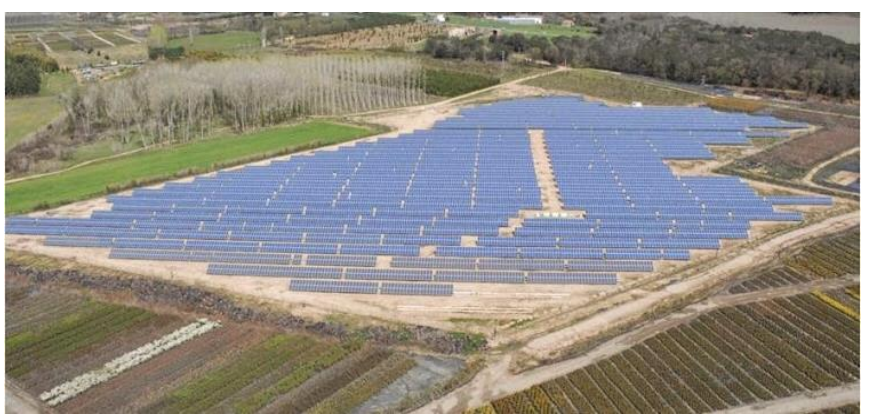

Figure. 1 photovoltaic farm in Spain 

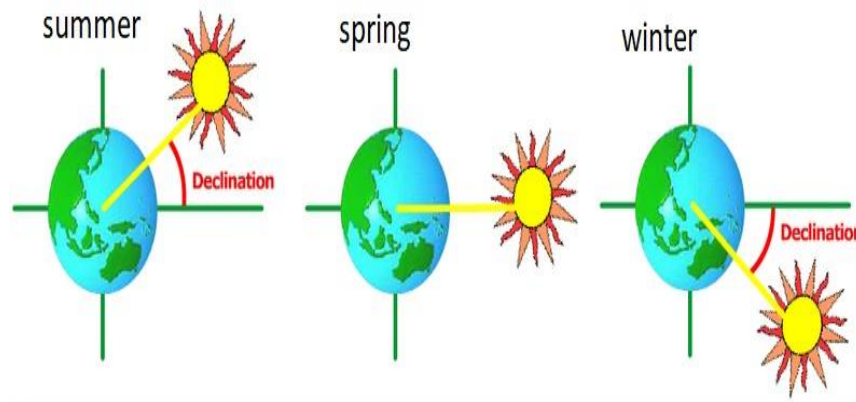

Figure. 2 solar declination

TABLE 2. BARCELONA PEAK HOUR (PSH)

\begin{tabular}{|c|c|}
\hline January & 2.09 \\
\hline February & 3.13 \\
\hline March & 4.3 \\
\hline April & 5.33 \\
\hline May & 6 \\
\hline Jun & 6.69 \\
\hline July & 6.8 \\
\hline August & 5.81 \\
\hline September & 4.56 \\
\hline October & 311 \\
\hline November & 2.14 \\
\hline December & 1.77 \\
\hline Average & 4.31 \\
\hline
\end{tabular}

The plus, and minus signs is used in Winter and Summer respectively. But these methods consider only the summer and winter but we have difference solar declination in each month and each season (see Fig. 2). Therefore, in this paper, we propose to determine the optimal tilt angle for all months. Qiu and Riffat [6], [7], Nijegorodov [8] in this paper proposed a relation for obtaining the optimal slope angle using only the latitude relationships for each month, Table 3 . Problem for this calculation is that it does not, include average monthly temperature and monthly average daily solar radiation on the horizontal surface.

The best method so far for determine the optimal sloping angles of PV panels is Klein Thekilacker method (KT method) $[9,10]$. in this paper improve this method because in the KT method only use of sunny day so we use in this paper of sunny day and semi cloudy day and cloudy day in a month for find best optimum tilt angle.

\section{MATHEMATICAL MODEL FOR SOlar RADIATION ON A HORIZONTAL SURFACE}

The average daily radiation on a horizontal surface $\mathrm{H}$ and it is be calculated with two components the direct irradiation $\left(\mathrm{H}_{\mathrm{dir}}\right)$ and the diffuse irradiation $\left(\mathrm{H}_{\text {diff }}\right)$ for each month and

TABLE 3. OPTIMUM SOLPE ANGLES WITH NIJEGORODOV RELATIONS

\begin{tabular}{|l|c|c|}
\hline \multicolumn{1}{|c|}{ Month } & $\beta_{\text {opt }}\left[^{\circ}\right]$ & $\begin{array}{c}\left.\beta_{\text {opt }}{ }^{\circ}{ }^{\circ}\right] \\
\text { for barcelona }\end{array}$ \\
\hline January & $0.89 \emptyset+29$ & 65.69 \\
\hline February & $0.97 \varnothing+17$ & 56.98 \\
\hline March & $\varnothing+4$ & 45.22 \\
\hline April & $\varnothing-10$ & 31.22 \\
\hline May & $0.93 \emptyset-24$ & 14.33 \\
\hline Jun & $0.87 \varnothing-34$ & 1.86 \\
\hline July & $0.89 \emptyset-30$ & 6.69 \\
\hline August & $0.97 \varnothing-17$ & 22.98 \\
\hline September & $\varnothing-2$ & 39.22 \\
\hline October & $\varnothing+12$ & 53.22 \\
\hline November & $0.93 \varnothing+25$ & 63.33 \\
\hline December & $0.87 \varnothing+34$ & 69.86 \\
\hline
\end{tabular}

The monthly temperature $\left(\Theta^{\circ}\right)$ was calculated $[11,12]$ and is presented in Table $4 . H_{O}$ is horizontal daily extraterrestrial radiation on the surface that can be estimated from

$H_{O}=\frac{86400 \times G s}{\pi} \times\left(1+0.033 \cos \left(2 \pi \frac{n}{365}\right)\right)$

$\left(\cos \phi \cos \delta \sin \omega_{s}+\omega_{s} \sin \phi \sin \delta\right)$

where:

- $G_{s}$ is the solar constant $\left(1367 \mathrm{~W} / \mathrm{m}^{2}\right)$,

$-n$ is number of day in a year.

$-\phi$ is the latitude (for Barcelona is $\phi=41.22^{\circ}$ ).

- $\omega_{S}$ is the sunset hour angle given by

$\omega_{s}=\operatorname{Arccos}(-\operatorname{tg} \phi \operatorname{tg} \delta)$

- $\delta$ is the solar declination evaluated as

$\delta=23.45 \sin \left(2 \pi \frac{284+n}{365}\right)$

We can see result of the evaluation $H_{O}$ in Fig. 3 . 


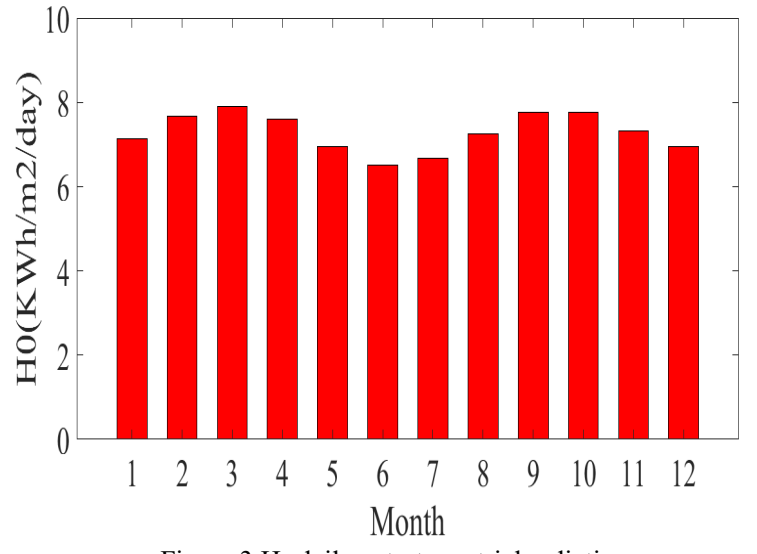

Figure. $3 \mathrm{H}_{0}$ daily extraterrestrial radiation

TABLE4. DAILY RADIATION ON A HORIZONTAL SURFACE AND MONTHLY TEMPERATURE

\begin{tabular}{|c|c|c|}
\hline Month & $\begin{array}{c}\mathbf{H} \\
\left(\mathbf{W h} / \mathbf{m}^{2} / \mathbf{d a y}\right. \\
)\end{array}$ & $\theta\left[{ }^{\circ} \mathrm{C}\right]$ \\
\hline January & 2180 & 7.2 \\
\hline February & 3150 & 7.3 \\
\hline March & 4770 & 10.3 \\
\hline April & 5550 & 13.6 \\
\hline May & 6810 & 16.8 \\
\hline Jun & 7550 & 20.9 \\
\hline July & 7460 & 24 \\
\hline August & 6430 & 23.7 \\
\hline September & 4950 & 20.7 \\
\hline October & 3610 & 17 \\
\hline November & 2380 & 11.9 \\
\hline December & 1920 & 7.7 \\
\hline
\end{tabular}

\section{KT MODEL}

The monthly-average index $\mathrm{KT}$ is the ratio of the monthly average daily radiation on a horizontal surface $(H)$ to the monthly average daily extraterrestrial radiation $\left(\mathrm{H}_{\mathrm{O}}\right)$ given by

$$
K T=\frac{H}{H_{0}}
$$

In this paper, we will propose an improvement to the KT method. The original KT method only considers clear days. But for for cloudy days, a slope angle of zero degrees for PV panels is assumed. Here, it is suggested to use four groups of sky situations and include coefficient for clear, partly cloudy, mostly cloudy and cloud days:

\section{Very clear sky: 1}

Clear sky: 0.8

Mostly cloudy sky: 0.4

Cloudy sky: 0
For performance assessment Table 5 is used [13] and the improved KT method is presented in the next section.

\begin{tabular}{|l|c|c|c|c|}
\hline TABLE. 5 SKY SITUATION FOR BARCELONA \\
\hline January & 14 & 12 & 2 & 3 \\
\hline February & 15 & 8 & 3 & 2 \\
\hline March & 17 & 10 & 3 & 1 \\
\hline April & 15 & 12 & 2 & 1 \\
\hline May & 18 & 8 & 4 & 1 \\
\hline Jun & 25 & 4 & 1 & 0 \\
\hline July & 29 & 2 & 0 & 0 \\
\hline August & 28 & 3 & 0 & 0 \\
\hline Septe mber & 23 & 5 & 1 & 1 \\
\hline October & 24 & 5 & 0 & 2 \\
\hline November & 21 & 5 & 2 & 2 \\
\hline December & 15 & 8 & 4 & 4 \\
\hline
\end{tabular}

\section{MATHEMATICAL MOdEl FOR SOlAR RADIATION ON A TILTED SURFACE}

In the proposed method, the total solar radiation on the tilted surface $\left(H_{T}\right)$ is calculated using

$$
H_{T}=H \times R=R \times K T \times H_{0}
$$

where $R$ is defined to be the ratio of the daily average radiation on a tilted surface to that on a horizontal surface for each month according to

$R=\left(1-\frac{H_{d}}{H}\right) \times R_{b}+\frac{H_{d}}{H}\left(\frac{1+\cos \beta}{2}\right)+\sigma\left(\frac{1-\cos \beta}{2}\right)$

where $R_{b}$ is the ratio of the average beam radiation on the tilted surface to that on a horizontal surface for each month as follows

$$
\begin{aligned}
& R_{b}=\frac{\cos (\phi-\beta) \cos \delta \sin \omega^{\prime}+\frac{\pi}{180} \omega^{\prime} \sin (\phi-\beta) \sin \delta}{\cos \phi \cos \delta \sin \omega^{\prime}+\frac{\pi}{180} \omega^{\prime} \sin \phi \sin \delta} \\
& \omega^{\prime}=\min \left\{\begin{array}{c}
\omega_{s} \\
\operatorname{Arccos}(-\operatorname{tg}(\varphi-\beta)) \operatorname{tg} \delta
\end{array}\right\}
\end{aligned}
$$

where "min" means the smaller of the two items in the bracket. The reflection coefficient of the incident radiation is between 0.2 and 0.7 as follows

$$
\sigma= \begin{cases}0.2 \quad, \quad \theta \geq 0^{\circ} \\ 0.2-0.1 \theta, \quad-5^{\circ}<\theta<0^{\circ} \\ 0.7, \quad \theta \leq-5^{\circ}\end{cases}
$$




\section{APPLICATION}

The optimized angle obtained for each month, each season and annual, according to the new KT method is presented inTable 6.

Fig. 4 shows the optimum monthly, seasonal, annual tilt angles. As can be seen in the summer months the optimum angle is $13.67^{\circ}$ But, the optimum tilt angle increases during the winter months until $56.46^{\circ}$.

Table 7 shows the radiation that would be obtained on the horizontal plane and for the optimal angle in Barcelona. Solar radiation is a bit less in the summer months but it has increased in other months of the year.

Thus, the proposed approach provides the annual optimum inclination maximizing the annual average. In this case, for the city of Barcelona, the radiation for the optimal angle $\left(36.87^{\circ}\right)$ is $5647 \mathrm{Wh} / \mathrm{m} 2 /$ day, while on a horizontal plane is $4730 \mathrm{Wh} / \mathrm{m} 2 /$ day. This represents an annual gain of $19.38 \%$. By using the obtained optimum slope angles of PV panels we can calculate the total radiation on the inclination surface.

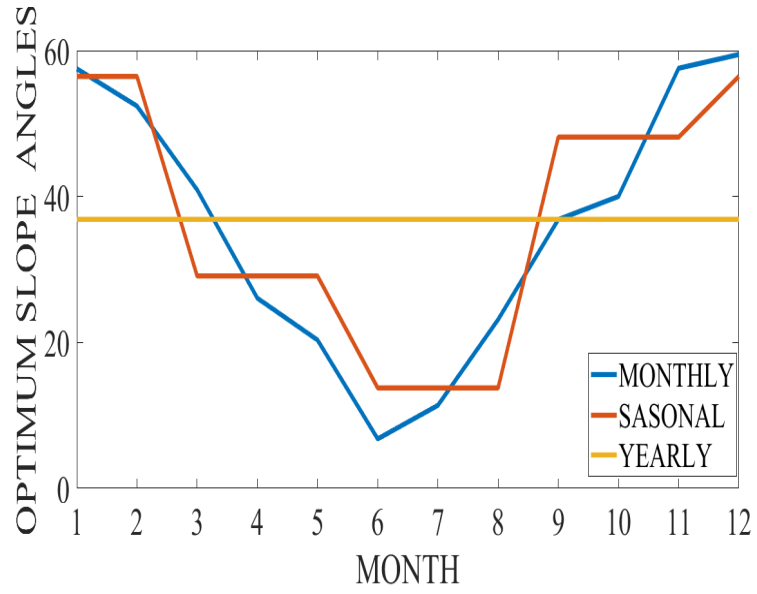

Figure.4 optimum monthly, season, annual tilt angle

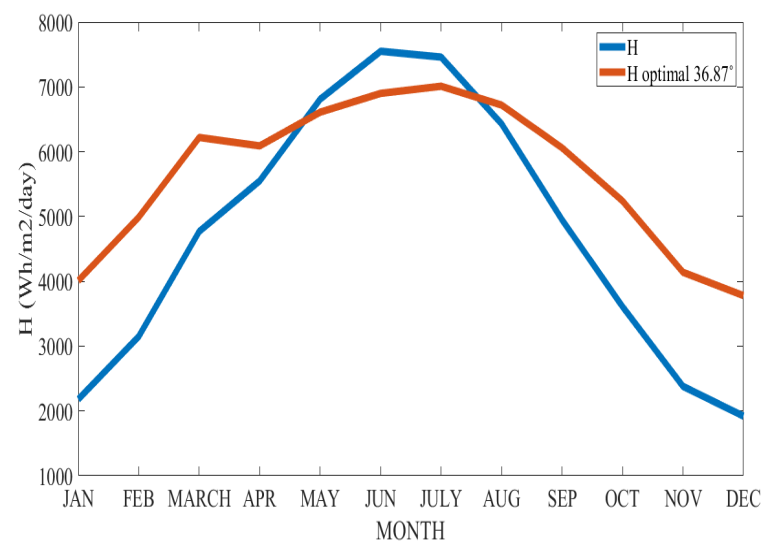

Figure.5 Comparison of $\mathrm{H}$
TABLE 6. OPTIMUM TILT ANGLE

\begin{tabular}{|c|c|c|c|}
\hline Month & $\begin{array}{l}\beta_{\text {opt }}\left[{ }^{\circ}\right] \\
\text { monthly }\end{array}$ & $\begin{array}{l}\beta_{o p t}\left[{ }^{\circ}\right] \\
\text { season }\end{array}$ & $\begin{array}{c}\beta_{\text {opt }}\left[{ }^{\circ}\right] \\
\text { yearly }\end{array}$ \\
\hline January & 57.51 & \multirow{2}{*}{56.46} & \multirow{12}{*}{36.87} \\
\hline February & 52.40 & & \\
\hline March & 40.92 & \multirow{3}{*}{29.11} & \\
\hline April & 26.07 & & \\
\hline May & 20.33 & & \\
\hline Jun & 6.78 & \multirow{3}{*}{13.76} & \\
\hline July & 11.38 & & \\
\hline August & 23.13 & & \\
\hline September & 36.84 & \multirow{3}{*}{48.14} & \\
\hline October & 50.01 & & \\
\hline November & 57.58 & & \\
\hline December & 59.46 & 56.46 & \\
\hline
\end{tabular}

TABLE. 7 COMPARE H BEFORE AND AFTER OPTIMAL ANGLE

\begin{tabular}{|c|c|c|}
\hline Month & horizontal & $\begin{array}{c}\text { optimum } \\
\text { angle }\end{array}$ \\
\hline January & 194.75 & 288.99 \\
\hline February & 240.13 & 286.76 \\
\hline March & 399.52 & 472.61 \\
\hline April & 472.61 & 499.05 \\
\hline May & 583.18 & 572.35 \\
\hline Jun & 626.33 & 585.41 \\
\hline July & 637.28 & 605.83 \\
\hline August & 561.83 & 571.81 \\
\hline September & 434.15 & 488.25 \\
\hline October & 318.18 & 409.99 \\
\hline November & 200.48 & 291.90 \\
\hline December & 176.61 & 282.99 \\
\hline sum & 4845.06 & 5355.94 \\
\hline
\end{tabular}

The total solar radiation on a tilted surface $\left(H_{T}\right)$ is calculated for each month and season as shown in Tables 8, 9 and 10 presented in the following. 
TABLE 8. TOTAL MONTHLY RADIATION FOR OBTAINED MONTHLY OPTIMUM SLOPE ANGLES

\begin{tabular}{|l|c|c|}
\hline \multicolumn{1}{|c|}{ Month } & $\begin{array}{c}\beta_{\text {opt }}\left[{ }^{\circ}\right] \\
\text { month }\end{array}$ & HT \\
\hline January & 57.51 & 1.14 \\
\hline February & 52.40 & 0.83 \\
\hline March & 40.92 & 0.89 \\
\hline April & 26.07 & 4.90 \\
\hline May & 20.33 & 6.20 \\
\hline Jun & 6.78 & 9.10 \\
\hline July & 11.38 & 8.20 \\
\hline August & 23.13 & 5.58 \\
\hline September & 36.84 & 4.03 \\
\hline October & 50.01 & 0.44 \\
\hline November & 57.58 & 1.01 \\
\hline December & 59.46 & 1.17 \\
\hline Average & & 3.62 \\
\hline
\end{tabular}

When the monthly optimum tilt angle was used, the yearly collected solar energy was $3.62 \times 10^{7} \mathrm{Wh} / \mathrm{m}^{2} /$ day. With the seasonally adjusted tilt angles, the yearly collected solar energy was $3.31 \times 10^{2} \mathrm{Wh} / \mathrm{m}^{2} /$ day. Finally, with the yearly average tilt angle, the yearly collected solar energy was $2.96 \times 10^{7} \mathrm{Wh} / \mathrm{m} /$ day. If the photovoltaic array set on monthly tilt angle has a reduction of $8.5 \%$ as compared to monthly and when photovoltaic array set on yearly tilt angle has a reduction of $10.5 \%$. (see Fig. 6). When using the yearly optimum angle, $\mathrm{H}_{\mathrm{T}}$ is reduced compared to monthly and seasonal optimum angle but presents an improvement of 7.95 $\%$ in yearly optimum angle as compared to yearly angle that was used in old method.

TABLE 9. TOTAL MONTHLY RADIATION FOR OBTAINED SEASONAL OPTIMUM SLOPE ANGLES

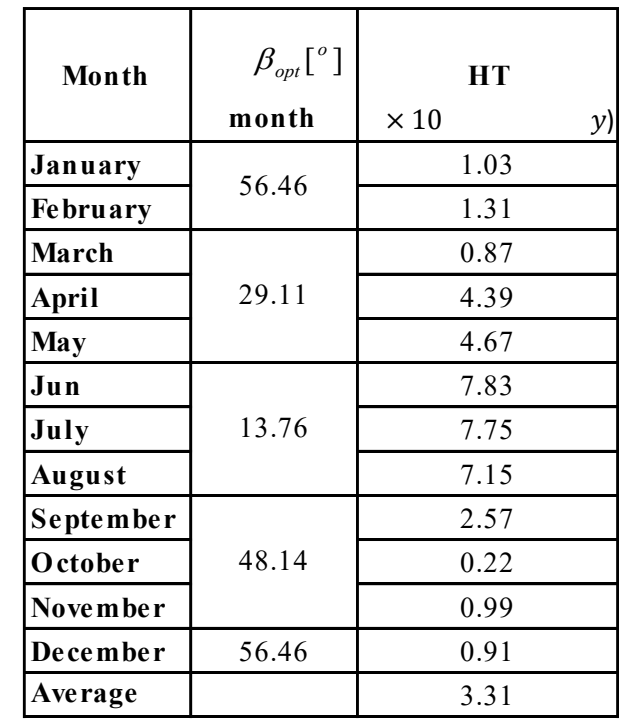

TABLE 10. TOTAL MONTHLY RADIATION FOR OBTAINED ANNUAL OPTIMUM SLOPE ANGLES

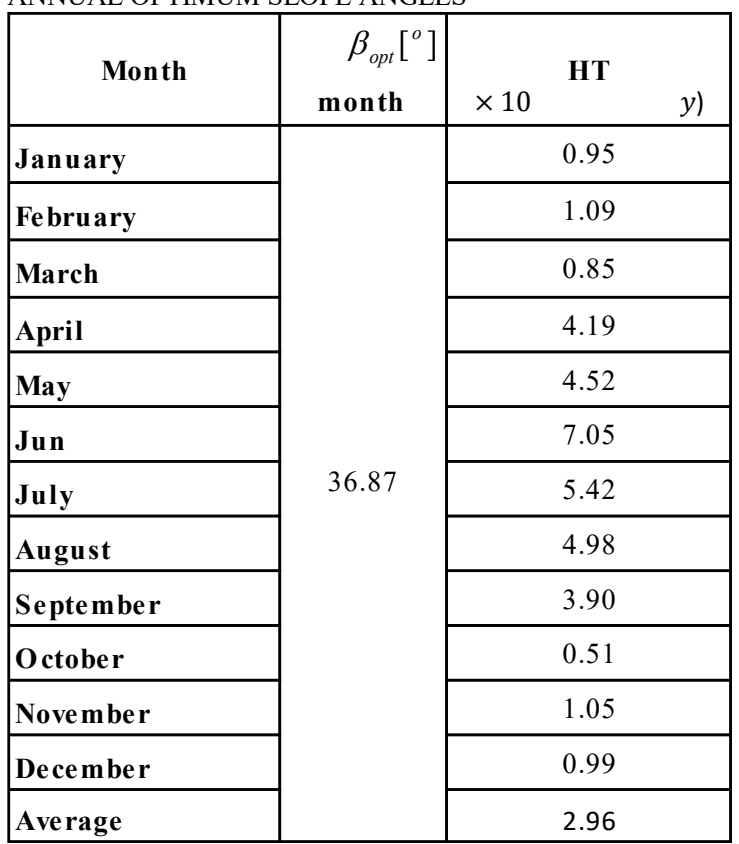

For a photovoltaic system with an installed peak power of 3 $\mathrm{kW}$ in Barcelona, Table 11 shows the monthly average value achieved with the optimal angle and with the old method.

Note that the energy generated is higher in summer months than in winter being proportional to the radiation. In a warm month, the amount of energy generated for a system with horizontal position is larger than the energy generated with optimal angle in May, Jun and July being respectively the energy generated for the horizontal case equal $583.18 \mathrm{KWh}$, $626.33 \mathrm{KWh}, 637.28 \mathrm{KWh}$. But, when optimal angle is used the energy generated is $572.35 \mathrm{KWh}, 585.41 \mathrm{KWh}$, $605.83 \mathrm{KWh}$. It has a reduction of $4.5 \%$ in May but in another month in a year presents more energy generated. So total energy generated in horizontal surface is $4845.06 \mathrm{KWh}$ and for optimal angle energy generated is $5355.94 \mathrm{KWh}$. Therefore, an improvement of $10.54 \%$ in the energy generated is achieved (see Fig. 7).

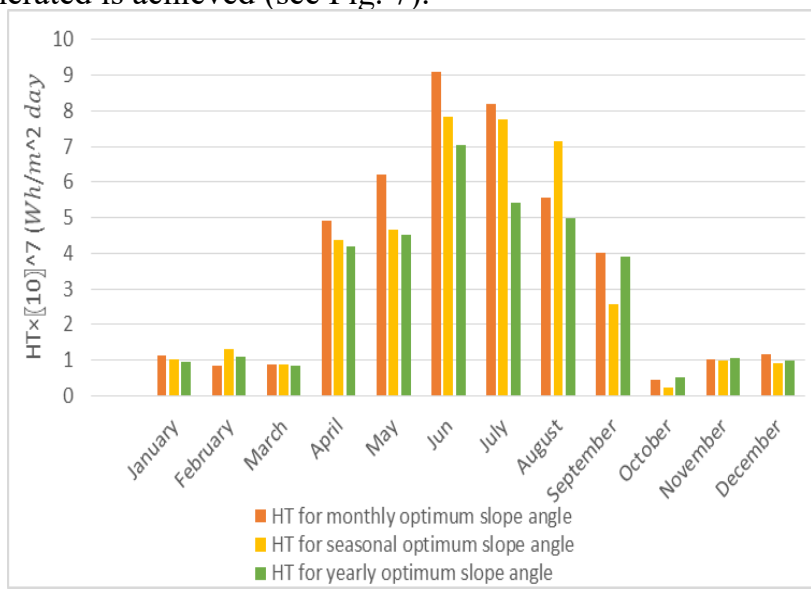

Figure. $6 \mathrm{H}_{\mathrm{T}}$ for monthly, seasonal, yearly tilt angles 
TABLE .11 ENERGY GENERATED IN BARCELONA

\begin{tabular}{|c|c|c|}
\hline Month & horizontal & $\begin{array}{c}\text { optimum } \\
\text { angle }\end{array}$ \\
\hline January & 194.75 & 288.99 \\
\hline February & 240.13 & 286.76 \\
\hline March & 399.52 & 472.61 \\
\hline April & 472.61 & 499.05 \\
\hline May & 583.18 & 572.35 \\
\hline Jun & 626.33 & 585.41 \\
\hline July & 637.28 & 605.83 \\
\hline August & 561.83 & 571.81 \\
\hline September & 434.15 & 488.25 \\
\hline October & 318.18 & 409.99 \\
\hline November & 200.48 & 291.90 \\
\hline December & 176.61 & 282.99 \\
\hline sum & 4845.06 & 5355.94 \\
\hline
\end{tabular}

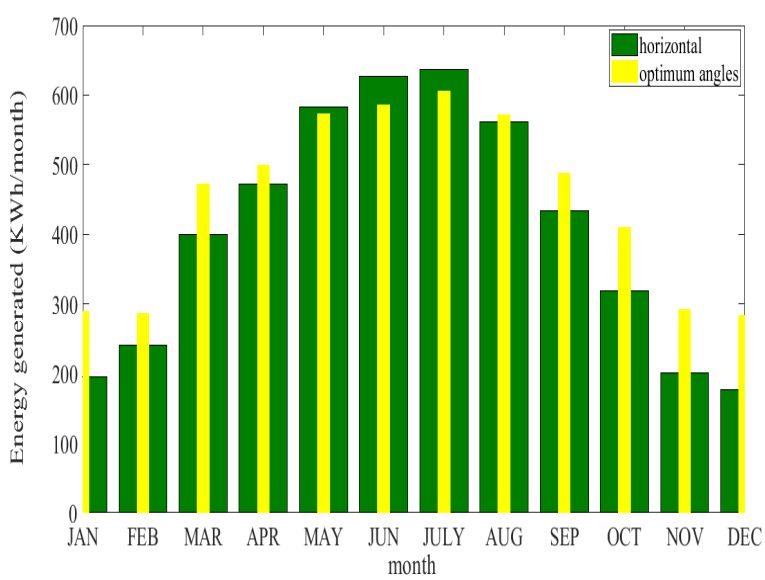

Figure. 7 compare energy generated in horizontal and optimal angles

\section{CONCLUSION}

Due to the different position of the earth and the sun in different months and seasons, as well as the position of the location for the installation of photovoltaic panels, the angle and absorption of sunlight will also be different. So, in order to generate more energy, the optimum angle for orienting the solar panels should be determined in order to collect the highest amount of solar energy to be converted in electrical energy. In this paper, the optimum angle for each month, season, and year is determined for the case of Barcelona city that is located at latitude 41o 22' 56" North and longitude 20 6'56" East. The optimum angle for summer is smaller than the winter angle for summer. In particular, the optimum angle is $13.67^{\circ}$ and for winter is $56.46^{\circ}$ and the year optimum angle is $36.87^{\circ}$.

Using the proposed approach, although the solar irradiation with optimum angle has decreased a bit in some month, for the majority of months have been increased, so the total solar irradiation has increased and achieved $5647.5 \mathrm{WH} / \mathrm{m}^{2} /$ day for energy generated with an improvement of $10.54 \%$ in the energy generated.

As further work, the proposed optimal orientation formula will be integrated with a control system for PV systems such that the panels are automatically oriented according to the month of the year.

\section{REFERENCES}

[1] G. O. Young, "Synthetic structure of industrial plastics (Book style with paper title and editor)," in Plastics, 2nd ed. vol. 3, J. Peters, Ed. New York: McGraw-Hill, 1964, pp. 15-64.

[2] W.-K. Chen, Linear Networks and Systems (Book style). Belmont, CA: Wadsworth, 1993, pp. 123-135.

[3] www.sunsolutions.es

[4] Duffie JA, Beckman WA. Solar Engineering of Thermal Processes. New York: Wiley, 1982

[5] Heywood H. Operational experience with solar water heating. J Inst Heat Vent Energy 1971; 39:63-9

[6] Qiu G., Riffat S. B., "Optimum Tilt Angle of Solar Collectors and Its Impact on Performance", International Journal of Ambient Energy, Taylor \& Francis, Vol. 24, Issue 1, 2003, pp. 13-20

[7] Lin WX. Optimum inclinations for the entire year for south-facing solar PV arrays in China. Energy 1989;14/12:863-6

[8] N. Nijegorodov, K. R. S. Devan, P. K. Jain, and S. Carlsson, "Atmospheric transmittance models and an analytical method to predict the optimum slope of an absorber plate, variously oriented at any latitude", Renewable Energy, Elsevier, Vol. 4, Issue 5, July 1994, pp. $529-543$.

[9] S. A. Klein and J. C. Theilacker, "An Algorithm for Calculating Monthly-Average Radiation on Inclined Surfaces", Journal of Solar Energy Engineering, ASME, Vol. 103, Issue 1, pp. 29-33, 1981.

[10] [7] S. A. Klein, "Calculation of Monthly Average Isolation on Tilted Surfaces”, Solar Energy, Vol. 19, 1977, pp. 325-329.

[11] Rus-Casas, C.; Aguilar, J.D.; Rodrigo, P.; Almonacid, F.; PérezHigueras, P.J. Classification of methods for annual energy harvesting calculations of photovoltaic generators. EnergyConvers. Manag. 2014, $78,527-536$

[12] http://re.jrc.ec.europa.eu/pvgis/apps4/pvest.php

[13] www.barcelona-weather.com 